University of Nebraska - Lincoln

DigitalCommons@University of Nebraska - Lincoln

Papers in the Earth and Atmospheric Sciences Earth and Atmospheric Sciences, Department

2008

\title{
Gender Imbalance in U.S. Geoscience Academia
}

\author{
Mary Anne Holmes \\ University of Nebraska-Lincoln, mholmes2@unl.edu \\ Suzanne O'Connell \\ Wesleyan University, soconnell@wesleyan.edu \\ Connie Frey \\ Southern Illinois University Edwardsville, cfrey@siue.edu \\ Lois Ongley \\ Unity College, longley@unity.edu
}

Follow this and additional works at: https://digitalcommons.unl.edu/geosciencefacpub

Part of the Earth Sciences Commons

Holmes, Mary Anne; O'Connell, Suzanne; Frey, Connie; and Ongley, Lois, "Gender Imbalance in U.S. Geoscience Academia" (2008). Papers in the Earth and Atmospheric Sciences. 57.

https://digitalcommons.unl.edu/geosciencefacpub/57

This Article is brought to you for free and open access by the Earth and Atmospheric Sciences, Department of at DigitalCommons@University of Nebraska - Lincoln. It has been accepted for inclusion in Papers in the Earth and Atmospheric Sciences by an authorized administrator of DigitalCommons@University of Nebraska - Lincoln. 
Published in Nature Geoscience (2008) 1(2): 79-82. Copyright 2008, Nature Publishing Group. Used by permission.

\title{
Feature
}

\section{Gender Imbalance in U.S. Geoscience Academia}

\author{
Mary Anne Holmes, ${ }^{1, *}$ Suzanne O'Connell, ${ }^{2}$ Connie Frey ${ }^{3}$ and Lois Ongley ${ }^{4}$ \\ ${ }^{1}$ University of Nebraska-Lincoln, Lincoln, Nebraska, USA; \\ ${ }^{2}$ Wesleyan University, Middletown Connecticut, USA; \\ ${ }^{3}$ Southern Illinois University-Edwardsville, Edwardsville, Illinois, USA; \\ ${ }^{4}$ Unity College in Maine, Unity, Maine, USA. \\ *e-mail: mholmes2@unl.edu
}

Geoscientists explain women's under-representation in our field along three dominant themes: the structure of academia, historically low numbers of women, and women's views and choices.

Which factor they perceive as most important depends overwhelmingly on their gender.

Diversity enhances problem solving, increases creativity and raises the level of critical analysis in work groups ${ }^{1,2}$. In a research environment, enhanced creativity should therefore produce better science. Unfortunately, the geosciences lag behind all other science, technology, engineering and mathematics fields (STEM) in terms of racial and ethnic diversity $3,4,5$. With respect to gender equity, we fare better than physics and engineering, but trail behind chemistry and the biological sciences $6,7,8$. About half of the undergraduate students in the geosciences are women, but as seniority increases, there is a precipitous decline in the proportion of women in geoscience academia. We are convinced that it is essential to attract more of this population into the field if the geosciences are to take advantage of the best minds. But how do other geoscientists perceive women's representation in their field? Do they see a problem, and if so, what do they see as the root causes? We have investigated geoscientists' perceptions using focus groups to address these questions.

\section{Women in the Geosciences}

To begin with, we investigated the proportions of female geoscientists in US academia. Women earned $42 \%$ of the Bachelor's, $45 \%$ of the Masters and $34 \%$ of the $\mathrm{PhD}$ degrees in the geosciences in 2004 (Figure 1; reference 8 ). The same proportion $(15 \%)$ of male and female undergraduate degree recipients in the year 1997 received a PhD in 2004 (estimated time to $\mathrm{PhD}^{9}$ ). So, although fewer women receive graduate geosci ence degrees than men, it seems they are retained through PhD programs, unlike in other STEM fields ${ }^{10,6}$. Moving up the academic ladder, the proportion of women geoscientists in entrylevel positions for academia in the US is significantly lower than the supply receiving the $\mathrm{PhD}$, and decreases more as the terminal degree offered is more advanced (Tables 1 and 2). But we found that after

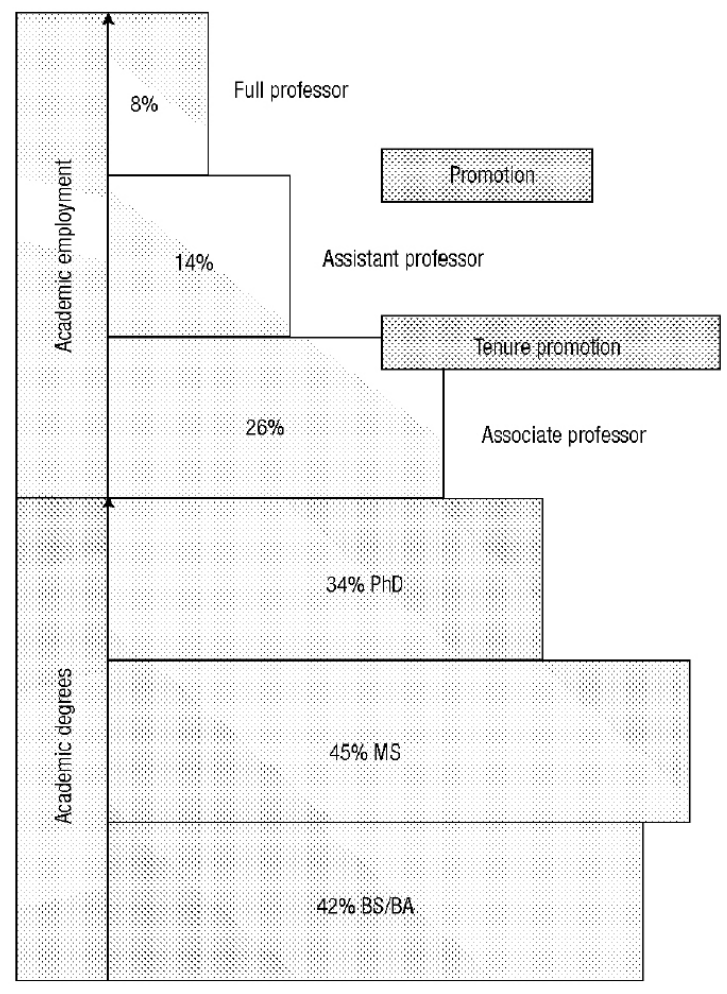

Figure 1 Proportions of women in each academic rank in US geoscience academia ${ }^{11}$. Women receive less than half of the undergraduate (BABBS: Bachelor of Arts or Bachelor of Science) and first post-baccalaureate degrees, MS (Master of Science). The apparent loss of women between the MS and PhD (Doctorate of Philosophy) degree reflects a time lag (that is, 10 years ago, women received one third of MS degrees), but the loss of women between PhD and assistant professor (entry-level academic position in the US) is real.

that crucial step to first position, men and women are promoted (and tenured) from assistant to associate professor at $\mathrm{PhD}$ granting institutions at comparable rates, although the numbers of women are very low. We followed a cohort of 80 men and 23 women who received $\mathrm{PhD}$ degrees between 1993 and 1996 and were listed in the 1996-1997 American Geological Institute's Directory of Geoscience Departments as "As- sistant Professor." After four years, in 2001, just under half of either gender were listed as "Associate Professor" whereas about a third were still listed as "Assistant Professor" The remaining $25 \%$ were missing from both the directory and departmental websites, indicating a voluntary departure from US academia or a failed tenure bid. The next step in the US is promotion to full professor. Only $8 \%$ of this top rank are women. 


\begin{tabular}{lllll}
\hline \multicolumn{5}{l}{ Table 1 Percentage of women at varying degree-granting institutions. } \\
\hline & $2004-2005$ & $2001-2002$ & $2000-2001$ & $1996-1997$ \\
\hline Bachelor's-granting & 18 & $17^{\star}$ & 16 & $11^{\star}$ \\
Master's-granting & $17^{\star}$ & 14 & 15 & $12^{\star}$ \\
PhD-granting & $13^{\star}$ & 12 & 12 & $9^{\star}$ \\
Total & 14 & 13 & 13 & $10^{\star}$ \\
\hline
\end{tabular}

\begin{tabular}{lcccc}
\hline \multicolumn{6}{l}{ Table 2 Percentage of women by rank at PhD-granting institutions. } \\
\hline \multicolumn{7}{l}{ 2004-2005 } & $2001-2002$ & $2000-2001$ & $1996-1997$ \\
\hline Assistant professor & $26^{*}$ & 23 & 21 & $20^{*}$ \\
Associate professor & 14 & 14 & 15 & 14 \\
Full professor & $8^{\star}$ & 8 & 8 & $5^{\star}$ \\
Chair, Head & $10^{*}$ & 8 & 6 & $4^{*}$ \\
\hline
\end{tabular}

*Statistically significant difference by 2; $p=0.05$

The retention of women through graduate school and comparable rates of promotion once on the tenure track suggests that most of the exodus of women from geoscience academia occurs at two critical junctures: during recruitment into the major (women earned $58 \%$ of all science degrees but only $42 \%$ of geoscience degrees in $2004^{10}$ ), and between the $\mathrm{PhD}$ and first academic position.

\section{Perceptions of Gender Balance}

We asked focus groups of academic geoscientists - composed of 40 women and 39 men in roughly equal distribution of seniority, ranking from students to full professors - which factors might explain the data described above (for more details on the focus group method, see Supplementary Information). We also asked them if the gender disparity we found mattered to them, and whether they believe that it has consequences for the quality of science, the research questions that are pursued or the approaches taken. We found that the focus groups' explanations for our data fall into three broad categories: structural issues related to academia, for example policies on family leave; the 'pipeline; by which participants see 'a historical artifact' of low numbers of women entering the field in the past; and reasons that lie with women's views and choices, including comments such as "women are choosing to not be geoscientists" or choosing not to be academics, and women lack self-confidence or the toughness necessary to succeed in academia.

Men and women placed different emphasis on each of these perceived issues, and men had more comments (141) than women (71) to explain the data. Most comments by women fell into the first category, reflecting frustration with the institution and its slow change to accommodate the changing workforce, with the second most commented on category being the pipeline (Figure 2). Only one comment by a woman referred to women's views and choices. Most men, in contrast, perceive the pipeline as the principal cause of the current lack of gender equity, followed by structural issues. Nearly $20 \%$ of male responses mentioned women's views and choices. In addition, four males had a unique response that no woman commented on: 'societal expectations' that women have children and that this would preclude their success in academia.

In addition to the statistically significant gender gap in perceptions there is a slight generational gap, particularly between advanced males (associate/full professors and administrators) and junior females (students and assistant professors). Few junior females attributed the data to pipeline issues and none mentioned women's views and choices as factors that explain the data.

\section{The Structure of Academia}

Participants suggested three types of structural barriers: family issues, lack of female mentors, and lingering chilly climates in some departments and/or institutions. Amongst the female participants, the most common explanation for the data was related to family issues that ranged from having to move when a husband got a job to feeling overwhelmed by the life of an academic after the birth of an additional child. Although some participants saw these as stumbling blocks from which women could not recover, advanced women with children uniformly did not. Women with children believe that this issue can be addressed if academic institutions offer affordable day care and uniformly applied flexible work arrangements that would better accommodate the overlap between the tenure clock and biological clock for women" (also see references in Supplementary Material).

More men than women see the lack of fe- male mentors as an issue. No advanced advanced female geoscientists mentioned the large positive impact of good male mentors. For female students, the lack of female role models interweaves with family issues. Sixty-nine percent of male tenure-track professors have children; only forty-one percent of female tenure-track professors $\mathrm{do}^{12}$ (based on a study of 37,000 faculty over all disciplines, 1978-1983). Students in our field are noticing this disconnect, as indicated by comments made during focus-group discussions. The lack of female mentors may not be an issue, but the lack of a role model whose life a female student may wish to emulate is.

Only one male participant mentioned 'climate issues' to explain the data, but this was the third most common explanation from women in our focus groups. Women mentioned lack of clear communication with advisors, being cut out of field opportunities, inappropriate posters on office walls, inappropriate comments, and heavy service loads (tokenism on committees). One male participant noted the presence of non-verbal discrimination in attitudes among his colleagues and comments that crop up only when "the women are not around."

Real structural barriers within academia, that are not specific to the geosciences, are slowing women's advancement. Sixty to eighty percent of women in scientific fields in academia indicate that balancing work with family is a major barrier..$^{13}$ It is worth pointing out that most women stay out of the corporate workforce for an average of only two years to cope with family issues. ${ }^{14,15}$ The good news is that there are family-friendly academic policies that are effective in facilitating women's retention. ${ }^{12,16,17}$ The ADVANCE portal website by Virginia Tech has useful strategies for lowering institutional, structural barriers. ${ }^{18}$

\section{The Pipeline}

The most common reason given by male participants, and the second most common reason given by female participants for the low numbers of women in academic positions is the pipeline, principally meaning that not enough time has passed to allow women to advance in academia, but also including low recruitment, low retention, and a sense that "time will solve this problem." But our data show that the exodus of women from academic careers - the lack of retention-will continue to slow the progress of the geosciences towards gender equity: $50 \%$ of women in our focus groups said they considered leaving the geosciences at some point, whereas only a third of men had. Women commented in our focus groups that they continue to contemplate leaving academia even after winning the 
brass ring of tenure. Considering the cost of a search-and-startup fund for new faculty (assuming the department gets to keep a vacated position), it seems that flexible work arrangements, including temporary parttime appointments, short-term leave and stop-the-tenure-clock to accommodate family issues is a better economic bargain for departments than letting a successful earlyto mid-stage career person leave. Leave policies must be institution-wide and applied uniformly and consistently. Negative discourse about these policies by faculty may be a significant barrier in their widespread application; institutional implementation from the highest administrative levels can reduce this. ${ }^{19,20}$ The high rate of nonretention for all assistant professors $(25 \%)$ is disturbing. This rate might be lowered by increased mentoring and guidance for all junior faculty. ${ }^{21}$

Women's Views and Choices

Is it something about women that precludes their advancement in academia? Ten male responses, and one associate/full female professor, suggested: "women are choosing a different career path," "females don't like field work," "females in general have a low interest in the subject matter," "females lack self-confidence," and "females in general prefer to teach."

A study on postdocs holding prestigious fellowships showed that some women's self-confidence is "extrinsic" or based on validation and encouragement from others. ${ }^{22}$ This perception could be altered by professional development training, such as the workshops offered by COACh. ${ }^{23} \mathrm{Sim}$ ply being aware that female students often need explicit encouragement and providing it may suffice to overcome such a barrier.

The assertion that a higher proportion of women are not as attracted to a dirt-laden field as men needs more study. As congenital players in the dirt, we would like to believe this is false. We probed students on the issue of 'image': that is, how are geoscientists perceived by non-geoscientists. There was widespread agreement among students that geoscience is a less attractive field for the 'fashion-conscious' However, this was not necessarily perceived as a bad thing, and not all student participants thought this affected women's participation in the geosciences.

Do women prefer to teach rather than do research? Women in our focus groups talked at least as much, or more, about their research as their teaching. Although it has been anecdotally suggested that women prefer to work at Bachelor's-granting institutions, our conversations with women in these positions indicate otherwise. Some women, as well as some men, prefer a larger teaching role; but others took the only available job. The higher teaching loads at such

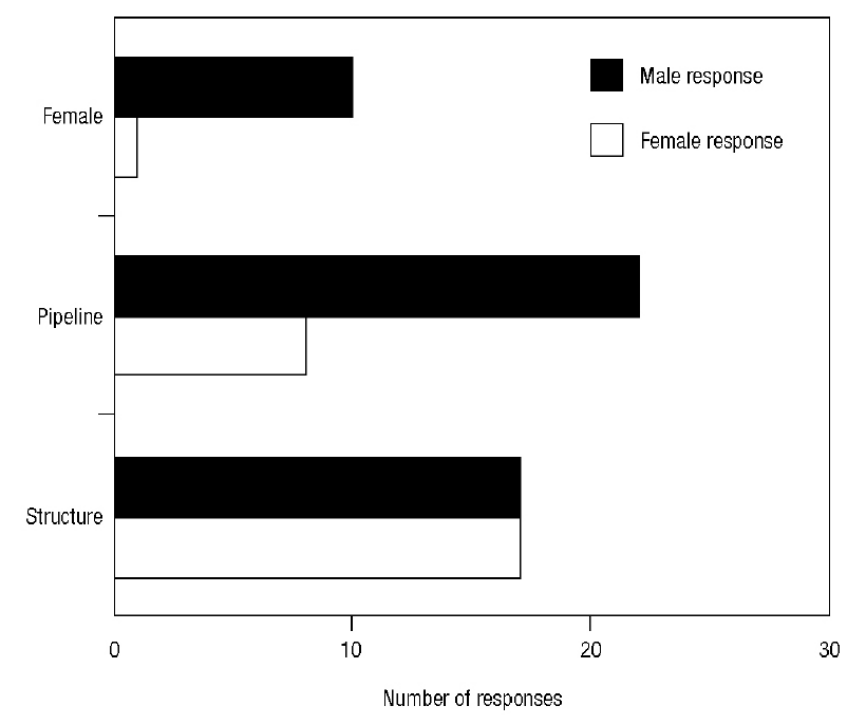

Figure 2 How male and female geoscientists explain the low numbers of women in academic positions in the US. Most male responses suggested that there is a 'pipeline' problem, and that with time, gender parity will be achieved. Most female responses suggested a 'structural' problem, that is, a problem with the way the tenure track and academic institutions are structured makes it difficult for women to cope with family issues and be a successful academic. "Female" refers to women's views and choices: that is, there are few women in geoscience in academia because women choose not to be there and/or women lack the skills or talent needed to succeed there.

institutions makes them no more family-friendly than research institutions. Do women get better jobs outside of academia? These data are hard to find. For now, the data we have show that women are getting advanced degrees, but they are not appearing in academic jobs, Anecdotal evidence suggests that women are not applying for academic positions after completing the $\mathrm{PhD}$. Academic search committees should assess who is in their applicant pool. If there are no women, a faculty should ask, "why not?" Too often search committees forget that 'search' is an active verb. We suggest that members of search committees attend conferences, seek out pre-tenure women scientists, invite them to give a talk in their colloquium series. An informal lookout can begin long before the formal search process does. Strategies to increase the diversity of applicant pools are provided by the University of Michigan. ${ }^{24,25}$

\section{Critical Mass to Gender Parity}

A threshold of $15-30 \%$ representation by minorities is thought to be enough to reduce the negative impacts of being a minority, but this proportion may not suit academia because women are not uniform in their attitudes and workstyles, ${ }^{26}$ What, then, would be the 'critical mass' for women in the geosciences? Several participants were not sure that a 50-50 split is achievable or even desirable.

Many geoscience departments, embarrassed by a complete absence of women on their faculty, recruited one woman, or perhaps even two, to their faculty in the 1980 s or 1990s. In smaller departments, this could have achieved 15 or $30 \%$ of women on staff, but these percentages can still translate to continued isolation for women faculty. And once one or two women were hired, further hiring often slowed. First hires may cope with isolation by retreating into a lab and not re-emerge to bond with newer hires.

Our results suggest that some advanced women may have adopted the 'traditional male' model: responses to the data were most similar between advanced males and advanced females. The focus group data from our students show that a mere proportion of women ignores the human side of the academic workplace.

We feel that it is time to abandon the concept of critical mass and focus instead on gender parity, a term defined as 'functional equivalence' We offer here a definition of gender parity for the geosciences: a department will have achieved gender parity when every student in it can look at the faculty and see at least one person whose life they wish to emulate. A department with only one woman or with five childless female full professors is not there yet. 
Ways of Achieving Gender Parity

With Libarkin and Kurdziel, ${ }^{22}$ we urge departments to learn where their specific losses are and what strategies can be developed to reduce this loss. Does the proportion of women in applicant pools come close to the PhD production rate or postdoc population? These data are available from the NSF websites ${ }^{5,7,8,10}$. If not, what might a department do to diversify its applicant pool? Exit interviews of both undergraduate and graduate students can reveal whether climate issues are affecting students. We can judge whether our perceptions agree with numerical data, and we can target our efforts where they will have the most impact.

We could wait for the pipeline to supply more women by having more women enter our programs, but the wait will be a long one: the proportion of women on the faculty will never equal the proportion receiving $\mathrm{PhDs}$ if we do not intervene to stop women's exodus from academia. ${ }^{27}$ The problem is not only the supply of women into geosciences majors, but the continual loss as more women drop out and head for other fields or other careers instead of tenure-track jobs and tenure. The processes by which our students complete $\mathrm{PhD}$ and go on to achieve tenure may not be selecting for all traits that can contribute to the best science and teaching. ${ }^{28}$ We assert from our own experiences and acquaintances that the ongoing loss of women from the geosciences is not 'best selection,' but a brain drain.

References

1. NAS: Committee on Maximizing the Potential of Women in Academic Science and Engineering and the Committee on Science, Engineering and Public Policy. 2006. Beyond Bias and Barriers: Fulfilling the Potential of Women in Academic Science and Engineering. (National Academies Press, Washington, D.C.).

2. Reagans, R. \& Zuckerman, E. W. 2001. Organization Science 12: 502-517.

3. Czujko, R. 2004. GSA Abstracts with Pro- grams 36: 278.

4. Czujko, R. \& Henley, M. 2003. Geotimes 48: 20-22.

5. National Science Foundation, Division of Science Resources Statistics. 2006. S \& E Degrees, by Race/Ethnicity of Recipients: 1995-2004 (NSF, Arlington, Virginia).

6. Nelson, D. 2007. A National Analysis of Minorities in Science and Engineering Faculties at Research Universities; available at http:/ / cheminfo.ou.edu/ djn/diversity/Faculty_Tables_FY07/ 07Report.pdf

7. National Science Foundation, Division of Science Resources Statistics. 2004. Women, Minorities, and Persons with Disabilities in Science and Engineering: 2004 NSF 04-317 (NSF, Arlington, Virginia); available at http://wwwnsf.gov/statistics/women.

8. National Science Foundation, Division of Science Resources Statistics. 2006. Science and Engineering Doctorate Awards: 2004 NSF 06-308 (NSF, Arlington, Virginia).

9. Hoffer, T. B. \& Welch, V. Jr. 2006. Time to Degree of U. S. Research Doctorate Recipients NSF 06-312 (NSF, Arlington, Virginia).

10. National Science Foundation, Division of Science Resources Statistics. 2006. Science and Engineering Degrees: 1966-2004 NSF 07-307 (NSF, Arlington, Virginia).

11. de Wet, C. B., Ashley, G. M. \& Kegel, D. P. 2002. Supplement to November 2002 GSA Today 12 (suppl.): 1-7; http://www. geosociety.org/pubs/ gsatoday/0211clocks/0211clocks.htm.

12. Mason, M. A. \& Goulden, M. 2004. Academe Online 90: 11-15 (November/ December 2004); available at http:// www.aaup.org/AAUP /pubsres/academe/2004/ND/ Feat/04ndmaso.htm.

13. Rosser, S. 2004. The Science Glass Ceiling: Academic Women Scientists and Their Struggle to Succeed (Routledge, New York).

14. Hewlett, S. A. \& Luce, C. B. 2005. Harvard Bus. Rev. 83: 43-54.

15. Shapiro, M. 2007. CGO Insights Briefing Note No. 25; available at http://www. simmons.edu/som/docs/centers/insights_25.pdf.
16. Williams, J. C. 2005. Chronicle of Higher Education 51: C1.

17. de Wet, C. B., \& de Wet, A. P. 1997. J. Women Minorities Sci. Eng. 3: 203-212.

18. http://research.cs.vt.edu/advance/index.htm.

19. Kirby, E. L. \& Krone, K. T. 2002. J. Appl. Commun. Res. 30: 50-77.

20. Drago, R. et al. 2006. Am. Behav. Sci. 49: 1,222-1,247.

21. Smock, P. T. \& Stephenson, R. 2004. Giving and Getting Career Advice: A Guide for Junior and Senior Faculty (University of Michigan's ADVANCE program, Ann Arbor; available at http://www.umich.edu/ advproj/careeradvising.pdf.

22. Libarkin, J. C. \& Kurdziel, T. P. 2003. J. Geol. Educ. 51: 446-452.

23. http:// coach.uoregon.edu/index.html.

24. http://sitemaker.umich.edu/advance/ stride.

25. Moody, T. 2004. Faculty Diversity: Problems and Solutions. (Routledge, New York).

26. Etzkowitz, H., Kemelgor, C., Neuschatz, M., Uzzi, B. \& Alonzo, T. 1994. Science 266: 51.

27. Marschke, R., Laursen, S., Nielsen, T. M. \& Rankin, P. 2007. J. High. Educ. 78: 1-26.

28. Georgi, H. 2000. APS News 9: 8 (January 2000).

Acknowledgements

This research was funded by the National Science Foundation ADVANCE program (award number 0123669), and by the Association for Women Geoscientists Foundation. Research methods were approved by University of Nebraska-Lincoln (IRB number: 2002-03-237). Discussions with Carol de Wet, Gail Ashley, Julie Winkler, and all participants at our workshop, "Where are the Women Geoscience Professors?" greatly aided our thinking regarding these issues and we thank them for their generosity.

Erratum: In Figure 1, the labels 'Assistant professor' and 'Associate professor' should be transposed. 